\title{
プリント板外観検査における新手法
}

\section{Novel Visual Inspection Methods for Printed Circuit Boards}

検査技術委員会

\section{1.はじめに}

本稿ではプリント板外観検査に関して最近注目される手 法について報告する。具体的には, プリント配線板パター ン検査, はんだ形状などの三次元形状検査, 濃淡むら検 查, 内部検查について検査手法の動向を概説し, 次いで研 究開発例を紹介する。

\section{2. プリント配線板パターンの検査}

プリント配線板パターンの外観検査自動化については従 来から多くの研究開発がなされてきた ${ }^{1), 2)}$ 。検査手法として は検査対象パターン情報と基準パターン情報を何らかの手 段で比較することにより欠陷を検出する手法が主である。 具体的な比較手法としては比較を画素ベースで行い不一致 部分を欠陥と判定する方式がある。基準パターンとして実 物パターンを用いる例や設計データを用いる例がある。画 素ベースの比較は精密な欠陷検査を実現できる可能性があ るが，精密な位置合わせが必要であり細かな変形による虚 報やが生じやすい。比較を画素ベースではなくパターンの 分岐や端点などの特徵や線幅を抽出して，これらを比較す る手法がある。この場合は, 両パターンの精密な位置合わ せは不要であり, 虚報は画素ベース検査よりも少なくでき る可能性がある。しかしこれらの特徵を抽出できない場 合，欠陷見逃しの可能性は高まる。

近年, 多数の CPU を使い並列画像処理を用いることによ り高速かつ精緻な画像処理が可能となってきた。これによ り多值画像処理が現実的となり, 従来では実現できなかっ た処理アルゴリズムの適用が可能となった。多值画像処理 を用いた配線パターンの検査手法として, 断線や短絡に加 えて配線の暗化部を欠陥として検査しようとする研究例が ある ${ }^{3)}$ 。

以下, 最近の最終プリント配線板パターン検查手法につ いて紹介する。

最終プリント配線板は, 端子, ランド, シルク印刷, は んだレジストなどの多層のパターンからなり, 単層パター ンの外観検査に比べて自動化には技術的な困難があった。
従来の開発例として蛍光検出および反射光検出により各層 のパターンを分離抽出して各層の公差に応じた検査基準で

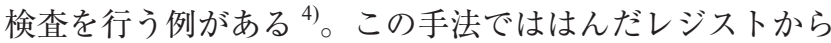
発生する蛍光を検出するのではんだレジストの色の変化に 左右されない検査が可能である。

最終プリント配線板パターン検査にはカラー画像処理が 適用されることが多い。カラー画像を使うことによって， はんだレジスト，導体部，シルク印刷部などの識別を行う ことができる。この場合パターンの検出にはカラーリニア イメージセンサが用いられる。この他に白黒リニアイメー ジセンサを加えて 4 チャンネルの検出を行う検査装置があ る ${ }^{5)}$ 。これはカラー画像検出に加えて白黒センサによって 高ダイナミックレンジの画像検出を行い低コントラストの 短絡などの欠陥を検出するために用いられる。また画素の 内挿 ${ }^{\dagger}$ 処理による高解像度画像処理を行い, 虚報を低減す るために位置合わせ精密化を行う。低光反射率の短絡欠陥 の検出は外観検査装置の課題であり，この検出能力を改良 するための試みとして注目される。

他の例としてパターン幅測長により検査を行う装置があ る ${ }^{6}$ 。画像の検出に TDI リニアイメージセンサ†を使い, 多コア CPU の並列処理によって高速画像処理を実現してい る。パターン幅測長による検査は, 以前からある手法であ るが柔軟な高速画像処理装置の採用によって実現したと言 える。

図 1 に示すように配線パターン中心線に沿って垂直方向 に多数の測長ラインを設定してパターン幅を測長する。測 長結果をマスター画像の測長結果と比較することにより欠 陥を検出する。パターンの明るさに追従して個々の測長ラ インで 2 值化閾值を設定することによりパターンの光反射 率の変化に対応する。パターン幅測長をする際, 画素の内 抻処理によりサブ画素（ピクセル）分解能で幅を測長する ことにより高精度で欠陥を検出することができる。測長に 適さない形状の検査はパターンマッチングにより検査す る。また多值画像処理により各層のずれや変形による虚報 の発生を抑える工夫をしている。 


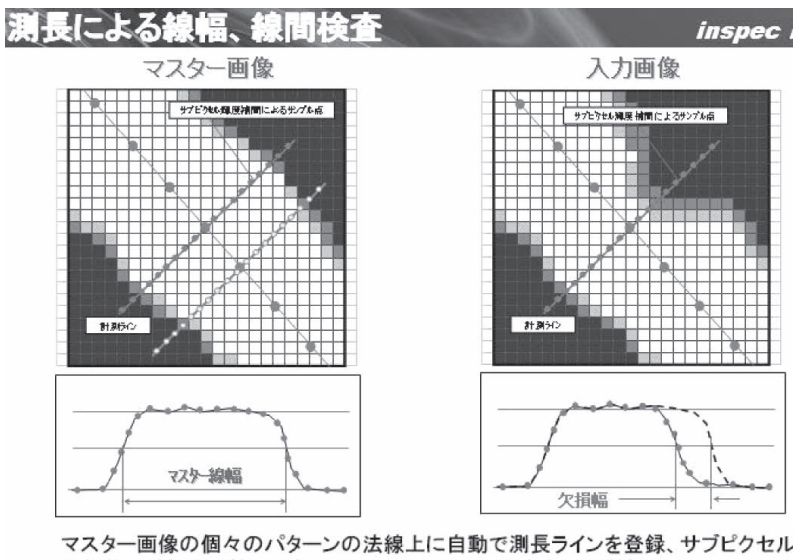

マスター画像の個々のパターンの法線上に自動で測長ラインを登録
分解能で線幅を比較し、パターンルールに沿って判定を行います。

図 1. 線幅の測長を用いた配線パターンの検査手法 ${ }^{6)}$

\section{3. 三次元形状検查}

三次元形状検査の例としては, はんだフィレット形状の 検査, 印刷はんだペーストの形状の検査, 搭載実装部品の 検査などがある ${ }^{7)}$ 。はんだフィレット形状を検査するには， 多段照明の照射角度を色や時間差で規定して, その反射光 の角度分布を検知することにより表面の傾きを計測する手 法が主流となっている。三次元形状検出で最も一般的に用 いられる手法は三角測量方式である。具体的には，スリッ ト光照射やレーザ光点走査による光切断法や, 複数方向か ら縞パターンを投影して縞パターンの変形（位相変化）か ら対象物の三次元情報を取得する手法がある。最近, 縞パ ターンを使う手法は, 搭載された実装部品検査や印刷はん だペースト検査に適用が進められている。三角測量方式 は, 対象物表面が鏡面反射性である場合適用が難しいとい う難点がある。その他に焦点情報を利用する手法がある。

三次元形状の検出に関して高速化の努力がなされてい る ${ }^{8)}$ が, 二次元画像検出と同等の速度を実現することは困 難である。これは検出するにも画像処理するにも次元が 1 つ多いため処理画素数が増え処理時間がかかるからであ る。検出速度を改善するための研究例を以下に示す。この ような新たな試みにより検査速度の向上が図られることが 望まれる。例えば配線パターン検査において配線の断面形 状を高速で検査する技術の開発が望まれる。

\section{1 印刷はんだペーストの三次元形状検査（多面ミラー} を用いた高速三次元形状計測)

通常の光切断法では 1 本の光切断線による像を二次元検 出器で検出し, 光切断線に沿った三次元プロファイルを抽 出する。このため 1 本の光切断線の計測に 1 フレーム分の 時間がかかる。多面ミラーを用いた高速三次元形状計測シ ステムを図 2(a)に示す 9)。同図に示す slit laser は 8 本の線 状レーザ光を対象物上に投影する。この線状レーザ光は対 象物上に光切断線を形成する。対象物からの反射光は multisided mirror（多面ミラー）により反射し, 各々の光切断線 の像を CMOS camera (二次元画像検出器) の短冊形の部分

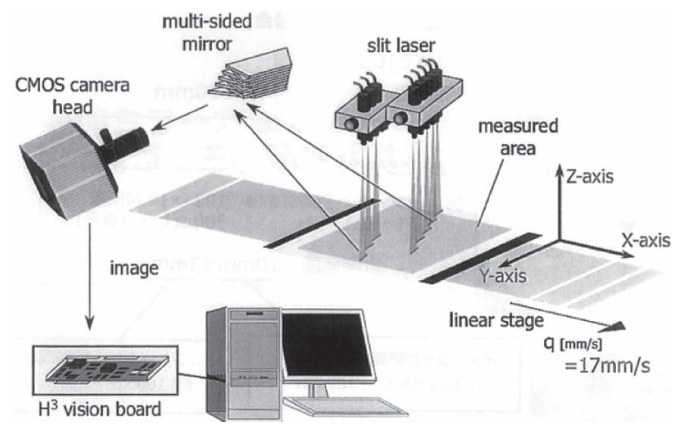

(a) 多面ミラ一を用いた高速三次元形状計測システム

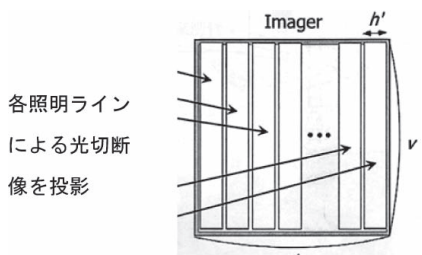

(b) カメラ撮像面

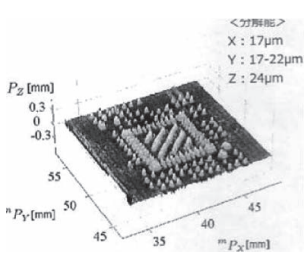

(c) 検出結果例
図 2. 多面ミラーを用いた光切断方式高速三次元形状計測 ${ }^{9)}$

に結像させる（同図 (b))。これにより 1 フレームで 8 本の 光切断線の象を検出して高さ情報を抽出することができ る。 $1,024 \times 1,024$ 画素の検出器を用いた場合, 疑似的に横 方向 8,192 画素, 高さ方向 128 画素の画像検出を行うこと ができる。

各短冊状の画像の処理は, 研究元が開発した高速画像処 理ボード $\mathrm{H}^{3}$ visionを用いることにより $1,000 \mathrm{fps}$ の速度で 断面形状を算出する。この速度は約 $8 \mathrm{MHz}$ の検出速度であ るので通常のリニアイメージセンサで画像を検出する速度 に相当する。画素サイズ $14 \mu \mathrm{m}$ の場合, 対象物の送り速度 $17 \mathrm{~mm} / \mathrm{s}$ で検出が可能である。図 2(c) は, 検出した印刷は んだペーストの例を示す。

\section{2 光沢面上の微小凹凸などの検出（高速光沢面スキャ ナ)}

プリント基板面の打痕など金属光沢面上の凹凸を検査す る場合，作業者は視点や対象物を傾けることにより，対象 物の光り方の違いから表面凹凸異常を検知する。これを実 用検査装置において実現するために多角度の照明光や多角 度で設置したカメラを用いることにより凹凸を検出するこ とが試みられているが人に伍する検査感度を実現すること は困難な課題である。

「高速光沢面スキャナ」 ${ }^{10)}$ では，前節に述べたカメラを用 い, 対象物に照射した照明ラインからの反射光を拡散光お よび鏡面反射光を含めて大きな開口角で検出する。高速画 像処理ボード $\mathrm{H}^{3}$ vision により画像の各短冊形の部分の反射 光を解析することにより種々の表面特性を計測することが できる。図 3 は, 表面に微小な凹凸がある対象物に対し て, 表面の傾き画像, 拡散光画像, 鏡面反射光画像, 表面 粗さ画像を計測した結果を示す。このような手法の高速 


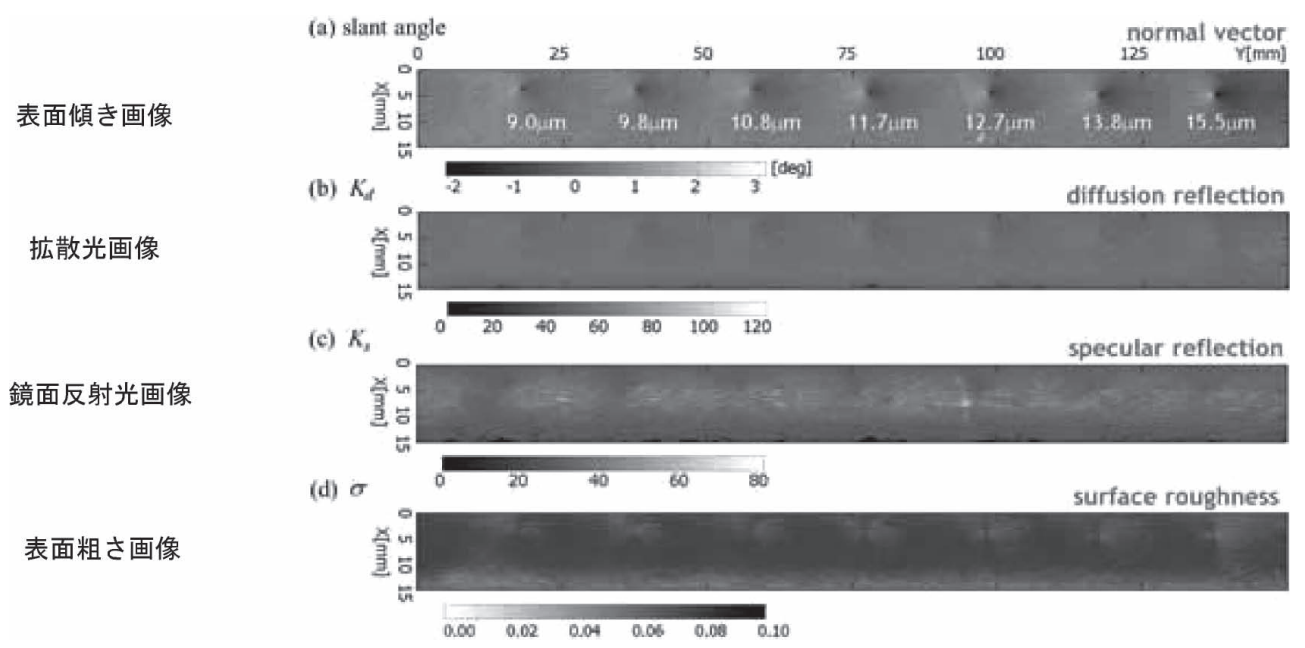

図 3. 光沢面上の微小凹凸などの検出 ${ }^{10)}$

化・実用化が望まれる。

\section{4. 濃淡むらの検査}

プリント配線板の基板, 端子, パッドなどの表面にでき る表面異常は製品の価值を下げ，また信頼性を低下させる 恐れがあることから，これを検査するための研究が行われ てきた ${ }^{11)}$ 。表面異常としては, 濃淡むら, 色むら, 污れ, 変色, 傷, 異物などがある。ここではこの内, コントラス トの低いむらを抽出する研究例について紹介する。

むらを抽出するためには, むらのない背景部分の輝度を 求めて, これと注目点の輝度を比較することにより抽出が 可能となる。緩やかに変化する背景画像の輝度を推定する ことができれば，これを基準值（2 值化閾值）とすること により，高周波成分からなるむらを抽出することができ る。このためにウェーブレットを用いて高周波成分を除去 することにより背景輝度を推定する手法や, 直接輝度分布 のプロファイルを認識する手法が研究されている。これら の手法は，むらが高周波成分からなるときに有効である。

また，むらの周囲の輝度を計測して，これを背景画像の 輝度として用いる手法がある。これはしばしば使われてい る手法であるが, 必ずしもむらの周囲の画像の輝度により 注目点の背景輝度を正確に推定できるわけではない。

むらは空間的に輝度が変化している部分であるので，微 分的な手法により，むらを検知する手法がある。この場合 は，むらの境界線部分の形状を抽出することになる。

\section{1 周辺輝度値の推定を柔軟に行う検査手法}

以上述べた手法の弱点を減らすために周辺輝度の推定を 柔軟に行うことにより，むらを抽出する研究がある ${ }^{12)} 。 そ$ の過程を図 4 に示す。画像をブロックで分割し, 個々のブ ロック内の平均輝度を求めて, 注目ブロックの輝度と他の ブロックの輝度を比較することにより画像の異常部分（む ら）を検知する。ブロックの境にむらがかかることがある ので，ブロックの位置（位相）を変化させ，またブロック

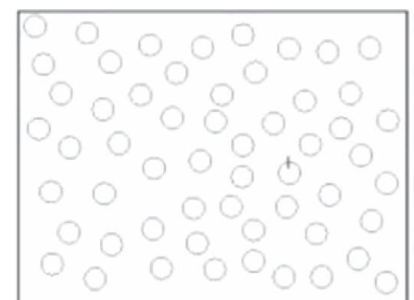

(a) Input image

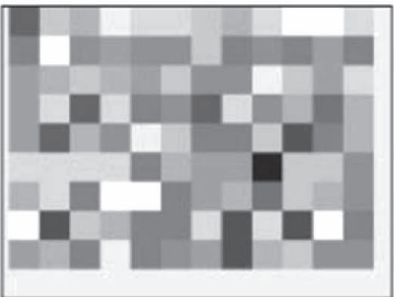

(c) Low resolution image

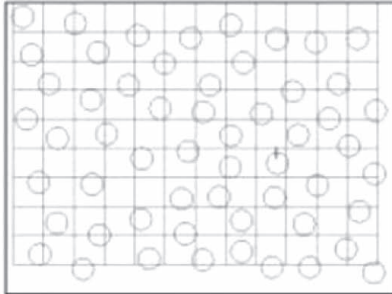

(b) Sampling lattice array

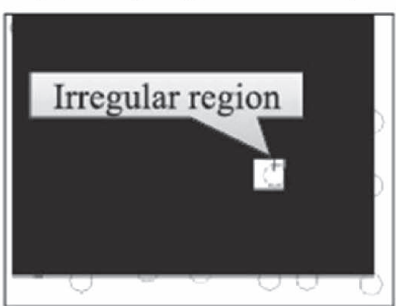

(d) Pop-out image
図 4. ブロック内の輝度比較によるむらの抽出 ${ }^{12}$

サイズを変化させながら評価を行うことにより種々の大き さのむら抽出に対応する。

本手法は，背景輝度推定の条件を柔軟に変化させながら 最適な条件を見つけ出して画像中の部分的な異常を抽出す る手法と言える。

\section{2 フーリエ変換を用いて梨地テクスチャ上のむらを抽} 出する手法

フーリエ変換を適用してむらを抽出する手法が提案され ている ${ }^{11)}$ 。画像をフーリエ変換し空間周波数面にフィル ターを置くことにより空間周波数を選択することができ る。フィルターの透過率が $1 （ 100 \%$ 透過）と0（不透過） で変化する従来用いられているフィルターを用いると良い 結果を得ることができない。本手法では周波数透過率がな だらかに変化する円環状透過帯域フィルターを用いて実験 を行った。図 5(a) 左は, 梨地テクスチャ上にあるむら画像 を示す。上方に小さなむら，中段，下段に行くにつれてむ らのサイズは大きくなっている。眓 5(a) 右は 2 值化画像で 

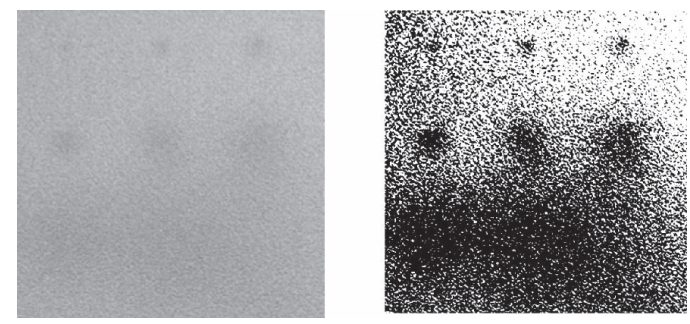

(a) むら画像および 2 值化画像
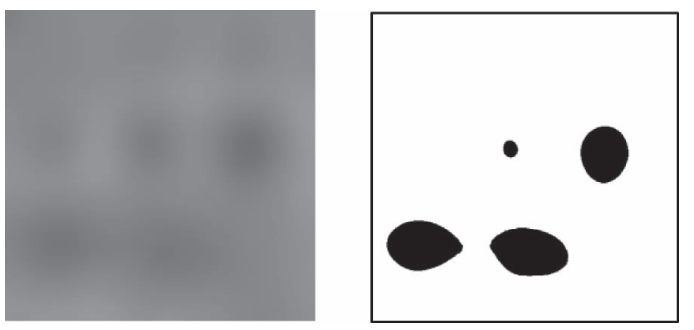

（b）大きなむらの抽出画像
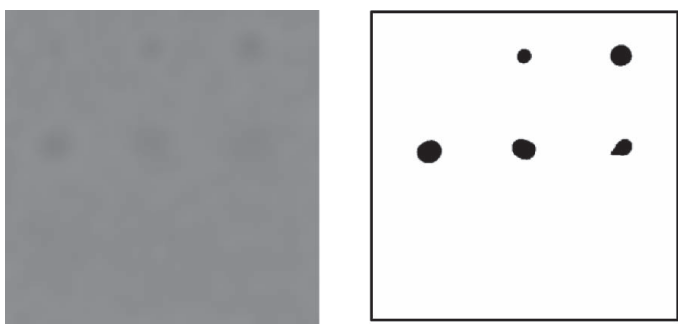

（c）小さなむらの抽出画像

図 5. 円環状周波数透過帯域フィルターを使った梨地テク スチャ上のむらの抽出 ${ }^{11}$

ある。むらと共に梨地テクスチャも2 值化されており，む らのみの抽出はできていない。

フィルターの円環の大きさを変えることにより通過周波 数带域を変えることができる。図 5(b) 左は比較的低周波数 の成分, 図 5(c) 左は, 比較的高周波数の成分を透過させて 再構成したむら画像を示す。図 5(b) 右では下方にある比較 的大きなむらが抽出されている。眓 5(c) 右では比較的小さ なむらが抽出されている。このように周波数带域を変える ことによりテクスチャの影響なしに低コントラストのむら が大きさごとに抽出されている。また緩やかに明暗が変化 する低周波画像を抽出するためには透過率が正規分布状に 変化する低周波数透過帯域フィルターが有効であることが 示されている。

\section{5. 内部検査}

実装板の高密度化に伴い内部検査がますます重要になっ てきている。これに対応して内部の三次元情報を取得する $\mathrm{X}$ 線 $\mathrm{CT}$ や内部の平面情報を検出する X 線ラミノグラフィ 技術が発展している ${ }^{13), 14) 。 ~}$

これらのX 線応用検查装置は物質によるX 線の吸収特性 の違いを利用している。したがってX線を吸収しにくい封 止材やアルミニウムなどの軽金属は検知できない。これら の物質を検知するには原子炉から放射される中性子線を適

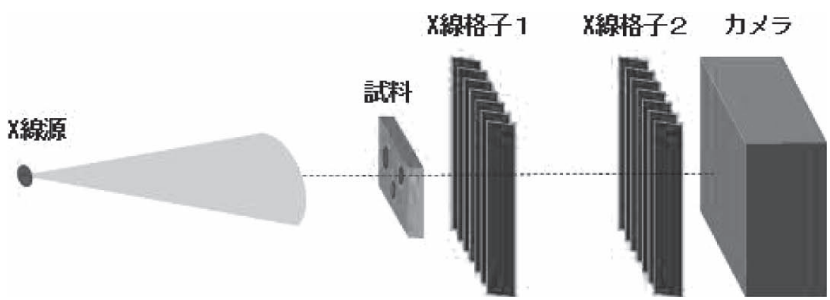

図 6. X 線タルボ干渉計システム ${ }^{16)}$

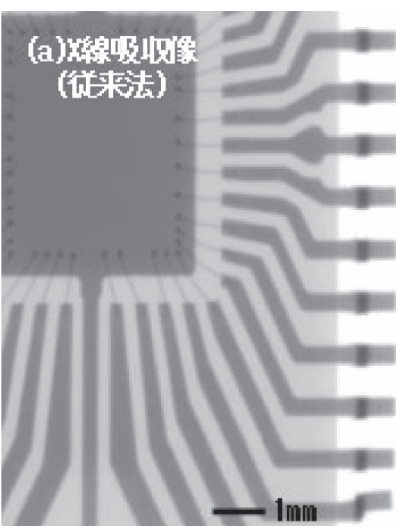

(a) X 線透過画像

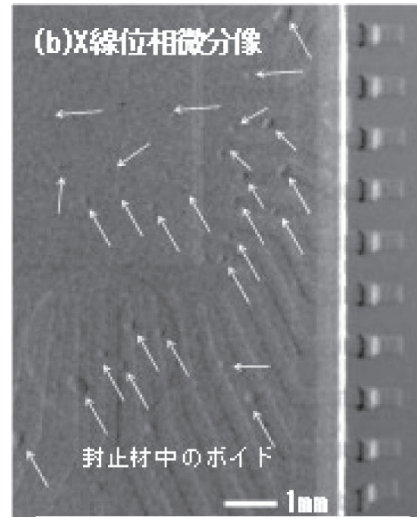

(b) タルボ干渉計位相微分像
図 7. 封止材中のボイドの検出結果 ${ }^{16)}$

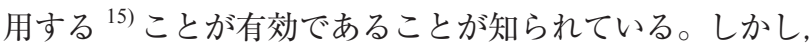
ここでは通常の X 線源により検知できる内部検査手段とし て注目されているタルボX 線干涉計を用いたX 線を吸収し にくい物質の欠陉可視化手法について紹介する ${ }^{16) 。}$

図 6 は, タルボ干渉計を説明する図である。通常の X 線 源から出た X 線を試料に照射する。試料の後ろには X 線格 子 1 が置かれている。試料を通過する際に生じるX X 線の位 相 (屈折) 変化によりX 線格子 1 の透過格子像に歪みが生 じる。これと X 線格子 2 によるモアレ像をカメラにより検 出する。これから, $\mathrm{X}$ 線吸収像, $\mathrm{X}$ 線位相微分像, $\mathrm{X}$ 線散 乱像を同時に取得することができる。図 7 は, 検出例を示 す。同図 (a) は, 通常の X 線透過像を示す。本手法では同 図 (a)では検出できない封止材中のボイドを, 同図 (b)に示 すように検出できていることが分かる。またクラックの検 出例も報告されている。検出分解能は $20 \mu \mathrm{m}$ と報告されて いる。本手法は, 実装板内部の解析手法として発展が期待 される。

\section{6. おわりに}

実装製品の形態は急速に発展している。これに対応して 外観検査自動化技術の開発が各所で進められている。本稿 では，この内いくつかの注目される外観検査手法について 紹介した。これらの手法がさらに発展して実用化されるこ とが望まれる。また検査は, 一層の高速化, 低コスト化, 種々の製品への対応，運用容易化などが求められている。 このためには検査技術部署だけではなく設計部署と連携し 
て DFT（Design for Testability ; 検查容易化設計）を適用す ることにより総合的な見地から製品の信頼性向上と製造コ スト低減を図るための努力が必要である。

文責・原 靖彦 /日本大学 (2014.10.24- 受理)

\section{文献}

1）原 靖彦：“検査技術の動向－外観検査, ” エレクトロニク ス実装学会誌, Vol. 2, No. 4, pp. 264-268, 1999

2）原 靖彦：“外観検査,”プリント回路技術便覧（第 3 版） 第 3 章, エレクトロニクス実装学会編, pp. 900-915, $2006 / 5$

3) 原 靖彦, 田中宏卓, 滝沢義信, 菅野純一: “濃淡変化方向 を考慮した比較方式プリント配線パターン外観検査, ”エレ クトロニクス実装学会誌, Vol. 17, No. 3, pp. 198-206, 2014

4) H. H. Kobayshi, Y. Hara, H. Doi, K. Takai, and A. Sumiya: “Hybrid defect detection method based on the shape measurement and feature extraction for complex patterns," IEICE Trans. Inf. \& Syst., Vol. E83-D, No. 7, pp. 338-1345, 2000

5) 墨岡 勉：“細部・暗部の欠陥検出力を向上させた高速・高 性能な最終外観検查装置の製品技術紹介, ”エレクトロニク 又実装学会官能検査自動化研究会第 2 回公開研究会予稿 集, pp. 33-40, 2013/1

6) 村上知宏 : “製品のばらつきに強い高感度, 高速フルカラー 最終外観検查装置, ”エレクトロニクス実装学会官能検査自 動化研究会, 第 3 回公開研究会予稿集, pp. 59-70, 2014/7

7) 安藤護俊：“はんだ付け部の検査技術,”回路実装学会誌,

Vol. 10, No. 7, pp. 482-485, 1995

8) 安藤護俊 : “実装プリント板の外観検査, ”エレクトロニク ス実装学会誌, Vol. 5, No. 4, pp. 332-335, 2002

9) 石井 抱, 藤井宏明, 山本健吉, 高木 健: “多面ミラーを 用いた三次元形状計測, ”日本機械学会論文集 C編, Vol. 76, No. 772, pp. 3405-3413, 2010

10) 石井 抱, 角田真一, 山本健吉, 高木 健: “表面反射特性 推定に基づく実時間光沢面スキャナの開発, ” 日本機械学会 論文集（C 編），Vol. 76, No. 763, pp. 603-610, 2010

11) 原 靖彦, 田中宏卓, 滝沢義信, 菅野純一: “濃淡むら抽出 法の概観とフーリエ変換を用いたむら抽出法の提案, ”エレ クトロニクス実装学会春季講演大会, 6B-05, 2014/3
12）青木公也, 船橋琢磨, 輿水大和, 三和田靖彦: “周辺視と個 視微動に学ぶ「傷の気付き」アルゴリズム,”精密工学会 誌, Vol. 79, No. 11, pp. 1045-1149, 2013

13）寺本篤司, 山田宗男, 村越貴行, 津坂昌利, 藤田広志：“傾 斜型 CT を用いた高密度実装基板解析, ”エレクトロニクス 実装学会誌, Vol. 10, No. 7, pp. 528-532, 2007

14）原 靖彦：“実装製品における非破壊検査技術, ”エレクト ロニクス実装学会誌, Vol. 4, No. 6, pp. 470-474, 2001

15) 安田 良：“中性子ラジオグラフィ一中性子による非破壊透 過試験一, ”エレクトロニクス実装学会誌, Vol. 15, No. 7, pp. $565-570,2012$

16）上原雅人：“タルボ干渉計を用いた $X$ 線非破壊検査の検討, ” エレクトロニクス実装学会官能検査自動化研究会, 第 3 回 公開研究会予稿集, pp. 75-80, 2014/7

\section{$\dagger$ 用語解説}

虚報：検査装置が「欠陥」として検出したにもかかわら ず合格範囲内であった場合を虚報（誤報，過検出）と いう。検査装置は虚報が少ないことが求められる。

画素の内挿：画像の拡大や画素を細分化する際，新たに

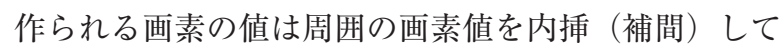
求める。これにより滑らかな画像拡大が実現する。ま た元の画素サイズ以下 (サブ画素) の精度での画像処 理や計測が可能となる。

TDI リニアイメージセンサ (Time delay integration linear image sensor) : リニアイメージセンサの受光素子を数 十段並べた形をしたセンサである。被写体の動きに同 期して受光信号を各段に転送することにより信号を積 算し高感度のセンシングを実現する。センサ部を複数 並列配置することにより 100～1,000 MHz の高速検出 を実現することができる。

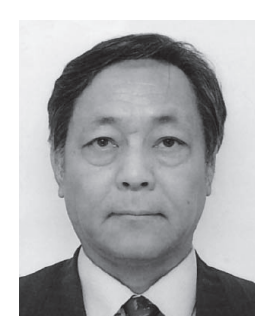

原 靖彦（はら やすひこ）

著者紹介 昭和 45 年東京工業大学大学院修士課程修了，同年 日立製作所入社。生産技術研究所において生産工 程における画像処理応用技術の研究開発に従事。 昭和 49 年 Carnegie Mellon 大学大学院留学。昭和 60 年工学博士 (東京大学)。平成 10 年日本大学工 学部情報工学科教授。現在同上席研究員。

エレクトロニクス実装学会, 精密工学会, 電子情 報通信学会会員。hara@cs.ce.nihon-u.ac.jp 